\title{
Copepod grazing potential in late winter in the Norwegian Sea - a factor in the control of spring phytoplankton growth?
}

\author{
U. V. Bathmann ${ }^{1}$, T. T. Noji ${ }^{2}$, B. von Bodungen ${ }^{3}$ \\ ${ }^{1}$ Alfred-Wegener-Institut für Polar- und Meeresforschung, Am Handelshafen 12, D-2850 Bremerhaven, \\ Federal Republic of Germany \\ ${ }^{2}$ Marinebiologisk Avdeling, Marine Biology Department, Boks 2550 Sør Tromsøya, N-9001 Tromsø, Norway \\ ${ }^{3}$ Sonderforschungsbereich 313, Universität Kiel, Olshausenstr. 40, D-2300 Kiel, Federal Republic of Germany
}

\begin{abstract}
During a winter cruise in the Norwegian Sea, vertical distribution of zooplankton as well as grazing and defecation by calanoid copepods from different water layers were investigated. An enriched population of natural phytoplankton ( $>4 \mu \mathrm{g} \mathrm{chl} \mathrm{al}^{-1}$ ) served as food in grazing and defecation. experiments. Results from chl a measurements and cell counts of the food medium before and after incubation with copepods as well as from HPLC analyses of copepod gut contents and scanning electron microscopy of the faecal pellets collected during these experiments revealed that copepods from the upper water layer ( 0 to $200 \mathrm{~m}$ ) were potential active feeders. Copepods from the water layers of their maximum abundance (below $500 \mathrm{~m}$ ) did not feed. Results implied that grazing of copepods already present in surface waters (surface overwinters) in late winter/early spring is a vital factor affecting the pelagic biological regime in spring
\end{abstract}

\section{INTRODUCTION}

In the Norwegian Sea, an increase in phytoplankton stock dominated by mid- to large-sized diatoms has been reported from late spring (Halldal 1953, Paasche 1980). Spawning of the major spring herbivore Calanus finmarchicus is reported to occur at the time of the phytoplankton peak in these latitudes (Hopkins et al. 1984), and is followed by an increase in zooplankton biomass (Wiborg 1954, Lie 1968, Marshall \& Orr 1972). However, in spring 1986 surface waters on the Voering-Plateau off Norway were dominated by nanophytoplankton of low biomass (Peinert et al. 1987), which is more typical of the summer situation in this area (Paasche 1980). The cause of this development was attributed to high grazing pressure by $C$. finmarchicus (Peinert et al. 1987). In this respect, phytoplankton species succession during that spring was similar to that in the North Pacific, where copepod grazing (mainly by Neocalanus cristatus and $N$. plumchrus) regularly occurrs during phytoplankton growth in spring (Dagg et al. 1982, Frost et al. 1983).

Since the studies of Østvedt (1955) and Lie (1968) it has been well known that the time of upward migration of deep-overwintering copepods at the begining of the growing season in the Norwegian Sea varies considerably from year to year. This timing in turn should influence the size and species composition of phytoplankton stocks; in situations of low zooplankton grazing, a stock of diatoms may be expected whereas less abundant smaller phytoplankters may be found associated with high zooplankton grazing (Paasche 1980, Smetacek et al. 1984). Such variations in the magnitude of copepod feeding may be also found in the North Atlantic where phytodetritus may reach the sea floor after a spring bloom (Billett et al. 1983) but does not do so regularly $(\mathrm{H}$. Thiel pers. comm.).

Factors determining the onset of the ascent of overwintering herbivores from depth and, hence, influencing the timing of increased zooplankton production, are unknown. From laboratory experiments it has been shown that increased food concentration (Mullin 1963) can induce activity in overwintering shallow-water copepods, yet at depth in the open ocean this may be of no importance. Although Colebrook (1985) postulated that the success of overwintering of copepods determines the size of their standing stock in spring of the following year, we know little of their winter survival 
strategy. Clues to defining the causes of such interannual variations, however, may possibly be found in understanding the influence of zooplankton on spring phytoplankton stocks. Hence, this became an important working hypothesis for this study.

In February 1987, as part of a joint research program (SFB 313) of Kiel University, a cruise with RV 'Poseidon' was undertaken in the Norwegian Sea. The aim was to determine the initial concentration and depth distribution of zooplankton standing stock and faecal pellets before the onset of spring phytoplankton development. Experiments were also conducted to assess the relative feeding potential of copepods from different depths. This allowed us to estimate the potential grazing effect of surface copepods in response to increases in phytoplankton growth.

\section{MATERIAL AND METHODS}

Between 2 and 22 February 1987 an investigation of the water masses on the Voering-Plateau (Norwegian Sea, Fig. 1) was conducted at 7 positions close to our permanent station. Vertical temperature and salinity profiles were recorded with a CTD probe (ME-Trap-

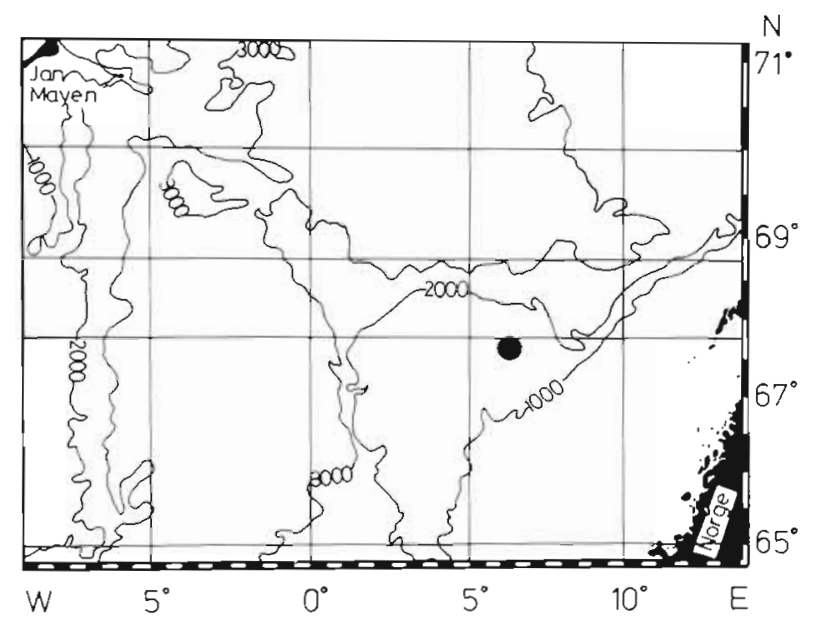

Fig. 1. Location of the permanent station $(\bullet)$ on the Voering Plateau in the Norwegian Sea

penkamp, FRG) at each station from the surface down to the sea floor (1270 to $1400 \mathrm{~m}$ ). Hydrocast samples (10l Niskin-bottles) from up to 15 depths at each station were filtered on precombusted Whatman GF/F filters and spectrophotometrically analysed for chlorophyll a (chl a) (Edler 1979). The chl a content was calculated using the equations of Jeffrey \& Humphrey (1975). Subsamples $(200 \mathrm{ml})$ were stored in buffered (borax) $0.4 \%$ formaldehyde-seawater solution. Cells larger than 5 um were counted using an inverted microscope (Utermöhl 1931, 1958). To convert phytoplankton cell volumes (calculated from form and dimensions of the cells; Edler 1979) to carbon (PPC), the factors of Strathmann (1967) and Smetacek (1975) were applied.

Zooplankton faecal pellets were collected in vertical hauls with a $20 \mu \mathrm{m}$ closing Apstein net at 4 depth intervals $(0-150,150-250,250-500,500-1000 \mathrm{~m})$. Preservation, counting and an estimate of carbon content lassuming a carbon:volume ratio of 0.11 ; Smetacek 1975) were conducted as for the hydrocast samples.

Mesozooplankton was collected in vertical hauls, using a $200 \mathrm{um}$ multiple opening and closing net (Hydrobios, Kiel, FRG), from 5 depth intervals $(0-150$, 150-250, 250-500, 500-750, 750-1000 m). The samples were stored in buffered (borax) $4 \%$ formaldehydeseawater solution for counting and identification to species level (sex and developmental stages of copepods were also determined under a dissecting microscope. For calculation of zooplankton carbonbiomass (ZPC) from individual numbers, factors listed in Table 1 were used. Zooplankton carbon content from fresh material was analysed after 3 min rinsing with distilled water using a Hewlett-Packard CHN-Analyzer (185 B).

For feeding experiments copepods were collected with a multiple opening and closing net fitted with closed $2 \mathrm{l}$ cod ends to prevent damage to specimens. Immediately after collection copepods were sorted under the dissecting microscope using cold light illumination. They were carefully transferred into glass bottles containing phytoplankton (about $15 \mu \mathrm{g} \mathrm{chl} \mathrm{a} 1^{-1}$ ) obtained from $1 \mathrm{~m}^{3}$ polyethylene tanks which had been previously filled with surface water and then illuminated with $120 \mu$ Einstein $(1 \mathrm{~m}$ water depth $)$ on a $16 \mathrm{~h}$ light $/ 8 \mathrm{~h}$ dark cycle for $10 \mathrm{~d}$.

Four series of experiments were conducted (Table 2): 2 series with copepods from surface waters (0-250 m; Expts I to III and IV to VI) and 2 with copepods captured at 750 to $1000 \mathrm{~m}$ water depth (Expts VII to IX). For Expts I to III and VII to IX, 15 to 20 copepods were placed into each of six 1.21 glass bottles containing the food medium (one concentration per series) described above; 2 additional bottles without copepods served as controls. Bottles were then placed into a dark, temperature-controlled $\left(5^{\circ} \mathrm{C} \pm\right.$ $0.2^{\circ} \mathrm{C}$ ) refrigerator $\mathrm{Chl}$ a content of the water before and after incubation was determined for each bottle. At the beginning and end of the experiment the bottle was mixed thoroughly but in a gentle way to prevent damage to the copepods. Thereafter, 5 copepods from each flask were removed randomly with a pipette and transferred into $1 \mathrm{ml}$ vials. Supernant water was removed by means of a pasteur pipette. The vials were refilled 2 times with filtered seawater (Whatman GF/F) 
Table 1. Length-carbon relations for some zooplankters

\begin{tabular}{|c|c|c|}
\hline Species/Group & Factor & Source \\
\hline Calanus finmarchicus $3.5 \mathrm{~mm}$ & $\mu \mathrm{g} \mathrm{C}$ & Robertson (1968) \\
\hline C. helgolandicus $4.2 \mathrm{~mm}$ & $\mu \mathrm{g} \mathrm{C}$ & Robertson (1968) \\
\hline C. hyperboreus $4.8 \mathrm{~mm}$ & $\mu g C$ & Conover \& Corner (1968) \\
\hline Metridia longa $2.9 \mathrm{~mm}$ & $\mu \mathrm{g} \mathrm{C}$ & Hopkins et al. (1978) \\
\hline M. lucens $2.5 \mathrm{~mm}$ & $\mu \mathrm{g} \mathrm{C}$ & Båmstedt (1975) \\
\hline Euchaeta norvegica $6.2 \mathrm{~mm}$ & $\mu g C$ & Båmstedt (1975) \\
\hline Heterorhabdus norvegicus $4 \mathrm{~mm}$ & $\mu \mathrm{g} \mathrm{C}$ & Båmstedt (1975) \\
\hline Pseudocalanus elongatus $1 \mathrm{~mm}$ & $3.61 \mu \mathrm{g} \mathrm{C}$ & Robertson (1968) \\
\hline Acartia sp. $1 \mathrm{~mm}$ & $2.79 \mu \mathrm{g} \mathrm{C}$ & Edler (pers. comm.) \\
\hline Temora longicornis $1 \mathrm{~mm}$ & $5.97 \mathrm{ug} \mathrm{C}$ & Hillebrandt (1972) \\
\hline Pleuromamma robusta $7 \mathrm{~mm}$ & $900 \mu \mathrm{g} \mathrm{C}$ & Bảmstedt (1975) \\
\hline Oithona sp. $0.8 \mathrm{~mm}$ & $0.83 \mu \mathrm{g} \mathrm{C}$ & Edler (pers. comm.) \\
\hline Chaetognatha $1.2 \mathrm{~cm}$ & $125.8 \mu \mathrm{g} \mathrm{C}$ & Bathmann (1988) \\
\hline Limacina retroversa $1 \mathrm{~mm}$ & $8.1 \mu \mathrm{g} \mathrm{C}$ & Bathmann (1988) \\
\hline L. retroversa $2 \mathrm{~mm}$ & $72.9 \mu \mathrm{g} \mathrm{C}$ & Bathmann (1988) \\
\hline
\end{tabular}

Table 2. Experimental set-up

\begin{tabular}{|lccc|}
\cline { 3 - 4 } Expt & $\begin{array}{c}\text { Depth of } \\
\text { capture }(\mathrm{m})\end{array}$ & $\begin{array}{c}\text { No. of } \\
\text { Calanus } \\
\text { finmarchicus }\end{array}$ & $\begin{array}{c}\text { Container } \\
\text { size (l) }\end{array}$ \\
\hline I & $0-250$ & 15 & 1.2 \\
II & $0-250$ & 18 & 1.2 \\
III & $0-250$ & 15 & 1.2 \\
IV & $0-250$ & $\sim 100$ & 25 \\
V & $0-250$ & $\sim 100$ & 25 \\
VI & $0-250$ & $\sim 100$ & 25 \\
VII & $750-1000$ & 16 & 1.2 \\
VIII & $750-1000$ & 20 & 1.2 \\
IX & $750-1000$ & 15 & 1.2 \\
X & $750-1000$ & -100 & 25 \\
XI & $750-1000$ & $\sim 100$ & 25 \\
XII & $750-1000$ & $\sim 100$ & 25 \\
\hline
\end{tabular}

to clear copepods from suspended algae. Then the samples were deep frozen and later analysed in the laboratory to determine the chl a content of the copepods by means of HPLC. For this, $1 \mathrm{ml}$ of $90 \%$ acetone, $5 \%$ water, and $5 \%$ solution ' $\mathrm{P}$ ' liquid (Mantoura \& Llewellyn 1983) was added to the frozen samples and copepods were hand-ground by means of a glass rod. The mixture was then sonicated for $5 \mathrm{~min}$ and placed in a refrigerator for $0.5 \mathrm{~h}$ to allow chlorophyll to extract. From this liquid, 100 to $250 \mu \mathrm{l}$ was injected for chl a determination by HPLC according to Mantoura \& Llewellyn (1983).

The remaining copepods were preserved and counted as for the other zooplankton samples. In addition, $200 \mathrm{ml}$ from each bottle was preserved for phytoplankton and faecal pellet counting under a light microscope. After counting, faecal pellets were isolated, dehydrated using a gradual alcohol series according to
Bathmann \& Liebezeit (1986), coated with goldpalladium (25 nm thick layer) and observed by scanning electron microscopy (SEM; Cambridge 150).

For the second series of experiments (Expts IV to VI and $\mathrm{X}$ to XII), 100 copepods were transferred into each of two $25 \mathrm{l}$ glass beakers containing the same food medium and concentration as in the experiments described above. After 0.5, 1, 2, 4, 9 and $18 \mathrm{~h}, 5$ copepods were removed and prepared for pigment measurements (HPLC), as described above.

\section{RESULTS}

\section{Field observations}

The hydrography was similar at each station on the Voering-Plateau. Temperature was nearly constant $\left(5.41^{\circ} \mathrm{C}\right)$ from the surface down to a water depth of $250 \mathrm{~m}$, below which it decreased gradually to $-0.95^{\circ} \mathrm{C}$ at $1400 \mathrm{~m}$ (Fig. 2). Salinity was always above $34.8 \%$ and a constant $36.1 \%$ between 0 and $250 \mathrm{~m}$ (Fig. 2).

Phytoplankton carbon (PPC) showed concentrations below $4 \mathrm{mg} \mathrm{PPC} \mathrm{m}{ }^{-2}$ (ca $16 \mu \mathrm{gPPC}{ }^{-3}$ ) in the upper $250 \mathrm{~m}$ of the water column (Fig. 3). Chl a concentrations in the water column were also very low (average $0.05 \mathrm{mg}$ chl $\mathrm{a} \mathrm{m}^{-3}$ ) and only once reached $0.12 \mathrm{mg}$

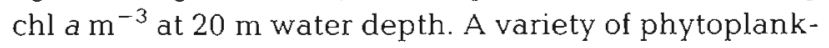
ton species was present (Ceratium spp., Dinophysis spp., Protoperidinium spp., Thalassiosira spp., Rhizosolenia spp., Detonula spp., Skeletonema costatum).

Numbers of copepod faecal pellets collected in the upper water column were up to 13000 pellets $\mathrm{m}^{-2}$ (Fig. 3). They contained few phytoplankton cells; most of the contents were microscopically unidentifiable (Fig. 4).

Zooplankton abundance in the top $250 \mathrm{~m}$ of water 


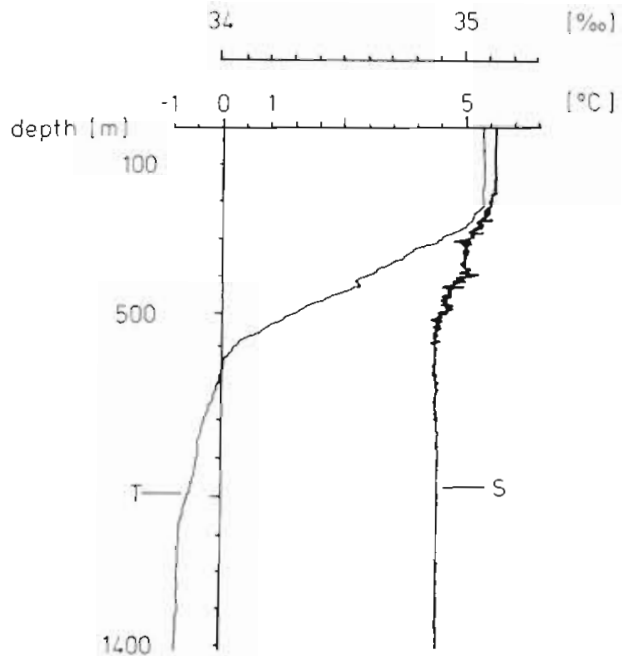

Fig. 2. Vertical distribution of salinity (S) and temperature (T) at the permanent station on the Voering-Plateau

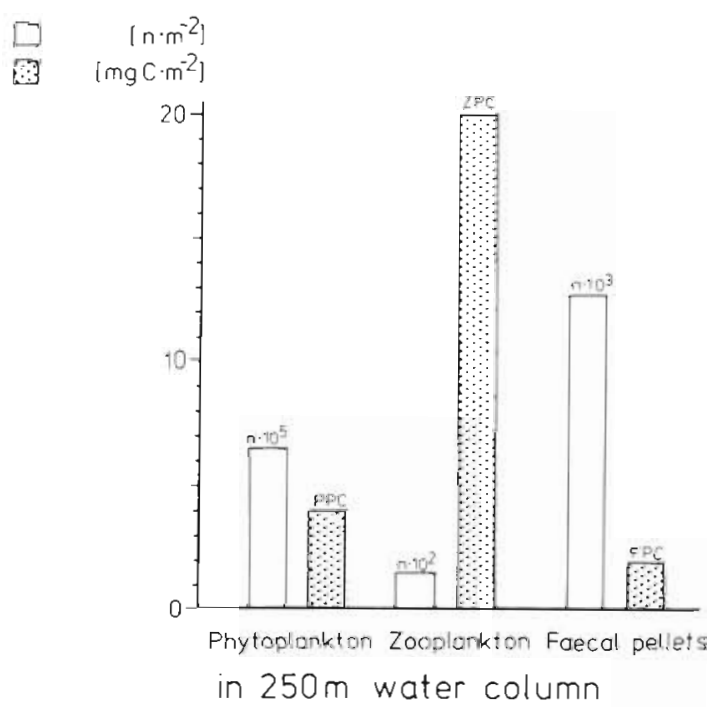

Fig. 3. Abundance $(\mathrm{n})$ and biomass $\left(\mathrm{mg} \mathrm{C} \mathrm{m}^{-2}\right.$, shaded columns) of phytoplankton, zooplankton and faecal pellets in the upper $250 \mathrm{~m}$ at the permanent station on the Voering Plateau

(average of all 7 positions during the study period)

was very low with ca $1.5 \times 10^{2}$ ind $\mathrm{m}^{-2}$ or $20 \mathrm{mg}$ zooplankton carbon $\mathrm{m}^{-2}$ (Fig. 3). The copepod Calanus finmarchicus was the dominating species; Metridia spp. was also present. Chl a concentrations in the guts of copepods were in the range 0.24 to $0.38 \mathrm{ng}$ copepod $^{-1}$ (Table 3). A much higher abundance of zooplankton was found in the deep water layers 1750 to $1000 \mathrm{~m})$ with ca $32 \times 10^{3}$ ind. $\mathrm{m}^{-2}(1.5 \mathrm{~g}$ zooplankton carbon $\mathrm{m}^{-2}$ ). Copepodite IV and $\mathrm{V}$, stages of $C$. finmarchicus were the dominant forms. Chl a concentrations in the guts of these copepods were below detection limits by HPLC.
Table 3. Example of peak identification in the pigment analysis by HPLC

\begin{tabular}{|c|c|c|c|c|c|c|}
\hline & \multicolumn{2}{|c|}{ Chlorophyll a } & \multicolumn{2}{|c|}{ Phaeophytin a } & \multicolumn{2}{|c|}{ Phaeophytin $b$} \\
\hline & $\begin{array}{l}\text { Time } \\
\text { (min) }\end{array}$ & $\begin{array}{c}\text { Height } \\
\text { (mm) }\end{array}$ & $\begin{array}{l}\text { Time } \\
\text { (min) }\end{array}$ & $\begin{array}{l}\text { Height } \\
(\mathrm{mm})\end{array}$ & $\begin{array}{l}\text { Time } \\
\text { (min) }\end{array}$ & $\begin{array}{c}\text { Height } \\
\text { (mm) }\end{array}$ \\
\hline Standard & 6.36 & 8.92 & 8.34 & 2.15 & 8.80 & 1.40 \\
\hline Sample & 6.30 & 3.54 & 8.25 & 0.40 & 8.75 & 0.22 \\
\hline
\end{tabular}

\section{Experiments}

During Expt I the initial chlorophyll concentration of $9.8 \mu \mathrm{g} \mathrm{chl} \mathrm{a} 1^{-1}$ was grazed down to $4.76 \mu \mathrm{g} \mathrm{chl} \mathrm{a} \mathrm{l^{-1 }}$ after $53 \mathrm{~h}$ of incubation (Fig 5). This corresponds to a filtration rate of $1.01 \mathrm{ml}$ copepod ${ }^{-1} \mathrm{~h}^{-1}$ (calculated after Omori \& Ikeda 1984) or about $1 \mathrm{ml}$ copepod ${ }^{-1} \mathrm{~h}^{-1}$ (extracted from Fig. 1 in Paffenhofer 1971). Grazing was most pronounced during the first $15 \mathrm{~h}$, during which time chl a decreased by $4.8 \mu \mathrm{g} \mathrm{chl} \mathrm{a} \mathrm{I}^{-1}$, equivalent to $3.59 \mathrm{ml}$ copepod ${ }^{-1} \mathrm{~h}^{-1}$. These results correspond with the observed reduction in total phytoplankton cell numbers from $2.02 \times 10^{6}$ cells $1^{-1}$ to $0.37 \times 10^{6} \mathrm{l}^{-1}$ (Fig. 5) during the $53 \mathrm{~h}$ period (grazing rate of $2.49 \times 10^{3}$ cells copepod ${ }^{-1} \mathrm{~h}^{-1}$ ). The initial food assemblage was dominated by Skeletonema costatum (10 um diameter)

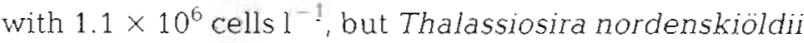
(10 to 30 um diameter; $0.6 \times 10^{6}$ cells $\mathrm{l}^{-1}$ ), Chaetoceros spp. $\left(100 \mathrm{um} ; 0.03 \times 10^{6}\right.$ cells $\left.1^{-1}\right)$, other diatoms (Nitzschia spp., centric diatoms with a diameter $10 \mu \mathrm{m}$; total $0.01 \times 10^{6}$ cells $L^{-1}$ ) and coccolithophorids ( 10 to $13 \mathrm{~km}$ in diameter) also were present. Relative species composition at the end of all experiments showed no significant changes as $S$. costatum and $T$. nordenskioldij accounted for more than $92 \%$ of all cells.

Zooplankton grazing during Expt II resulted in a decrease in chl a of $8.98 \mu \mathrm{g} \mathrm{chl.} \mathrm{a} \mathrm{l}^{-1}\left(1.3 \times 10^{6} \mathrm{cells}^{-1}\right)$ over the $53 \mathrm{~h}$ period (Fig 5). This corresponds to a filtration rate of $1.42 \mathrm{ml}$ copepod ${ }^{-1} \mathrm{~h}{ }^{1}$ As in Expt I, the most intense grazing was observed during the first $14 \mathrm{~h}$. period.

Faecal pellet production as evident from Expts I and II was similar in all experiments with surface copepods

Fig. 4. Scanning electron micrographs of faecal pellets from Calanus finmarchicus collected during the feeding experiments. (a) Pellet collected after $15 \mathrm{~h}$; rote the intact frustule of Thalassionsira spp. (b) Pellet after 15 h containing frustules of $T$. nordenskioldii, and remains of Skeletonena costatum. Nitzschia sp., Thalassiosira sp. and Chaetoceros spp. (c) Pellets collected at $53 \mathrm{~h}$ of the experiment showing only few identifiable remains of diatoms. (d) Enlargement of (c): most of the material is unidentifiable and only few diatom fragments can be found. Scale bars: (a) $100 \mu \mathrm{m}$, (b) $10 \mu \mathrm{m}$, (c) $20 \mu \mathrm{m}$. (d) $10 . \mathrm{mm}$ 

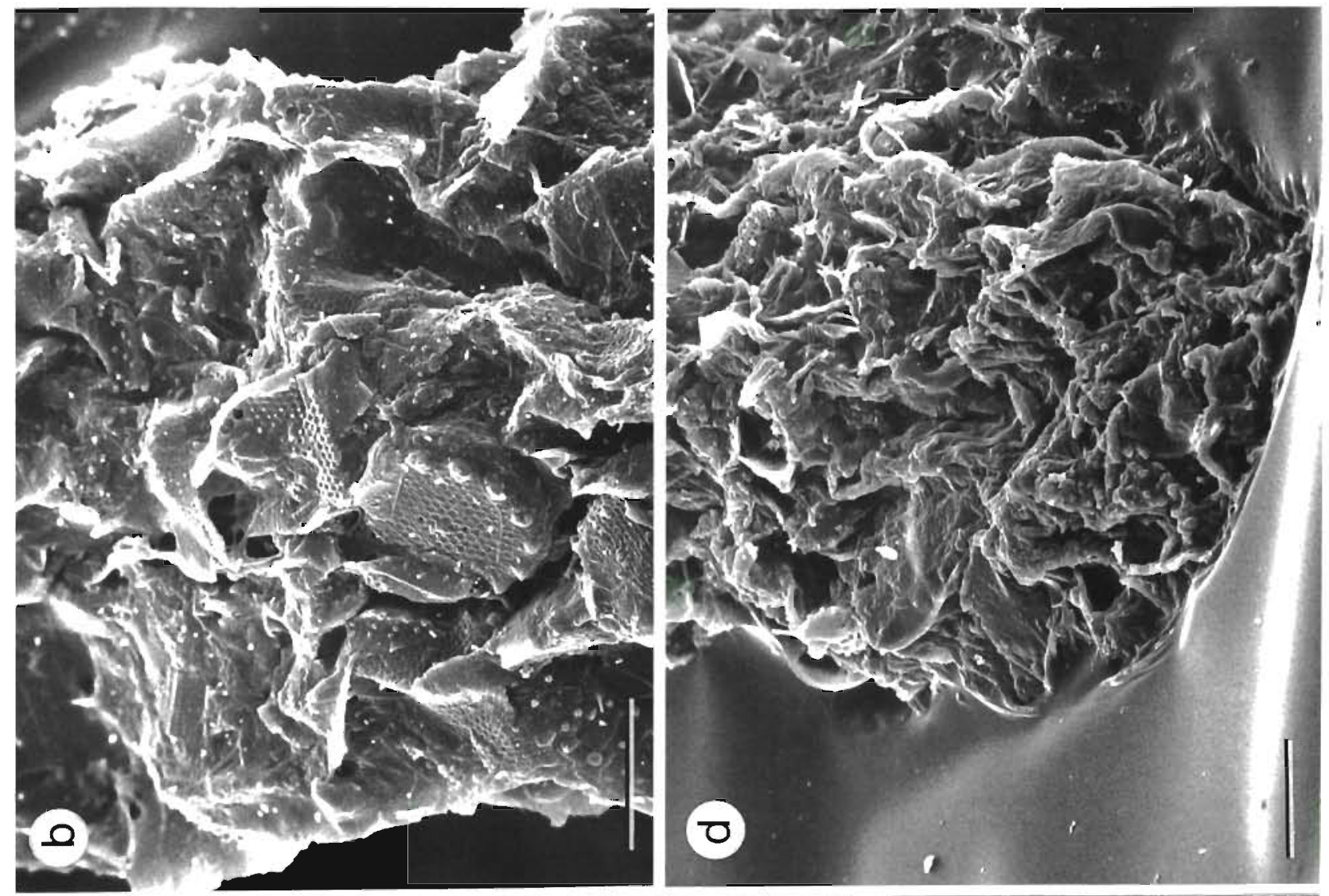

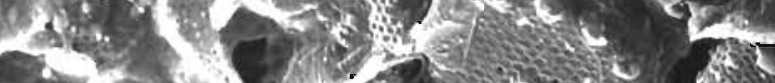
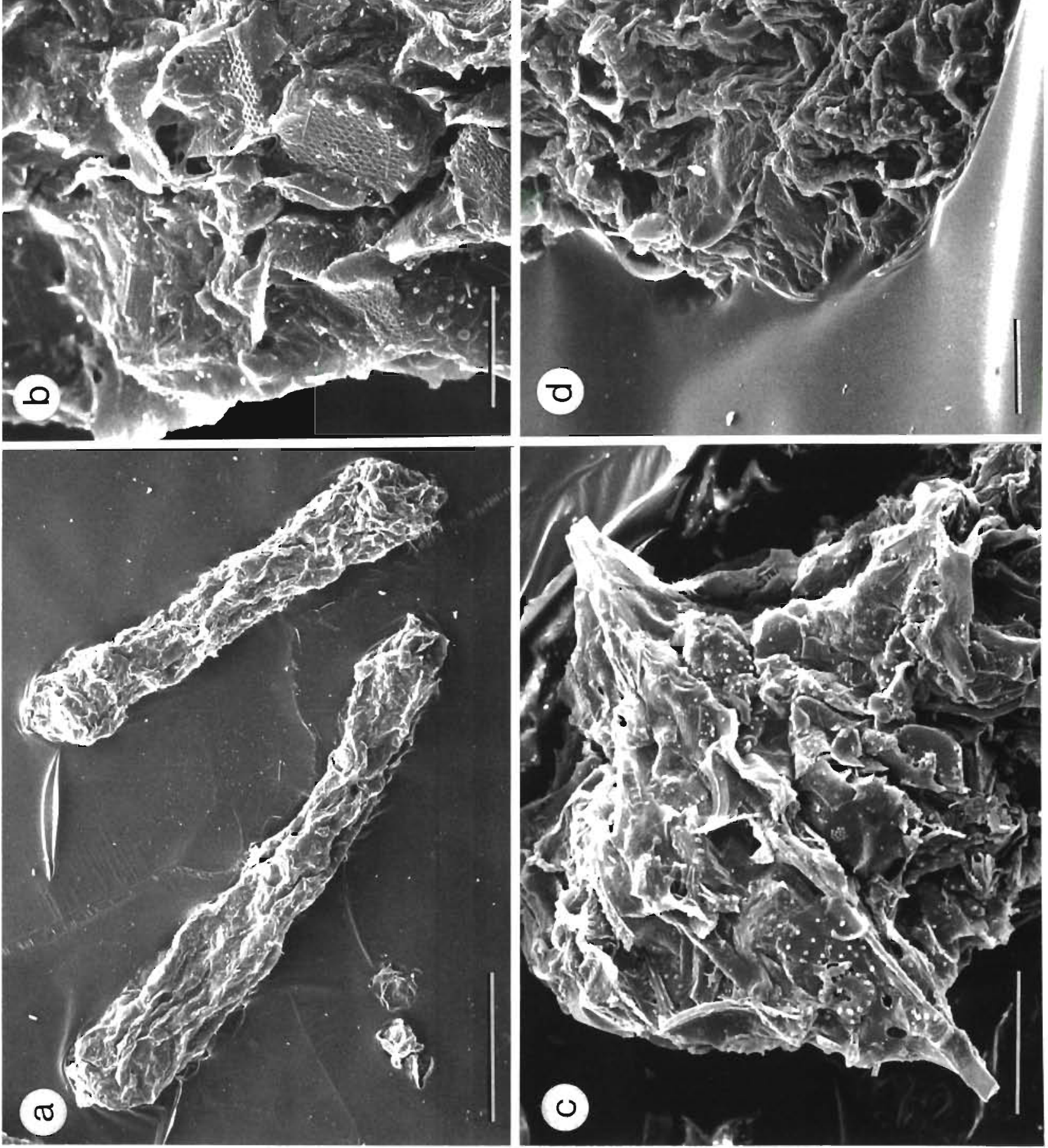


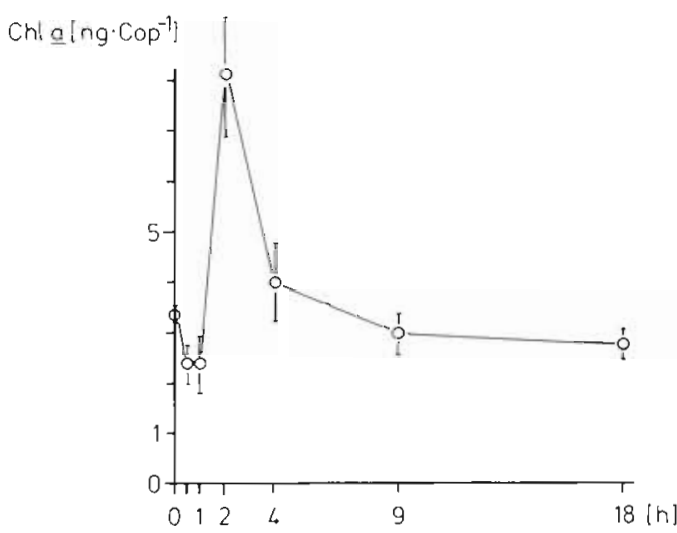

Fig. 5. Gut fluorescence (ng chi a copepod ${ }^{-1}$ ) during the first $18 \mathrm{~h}$ of the experiments determined by HPLC
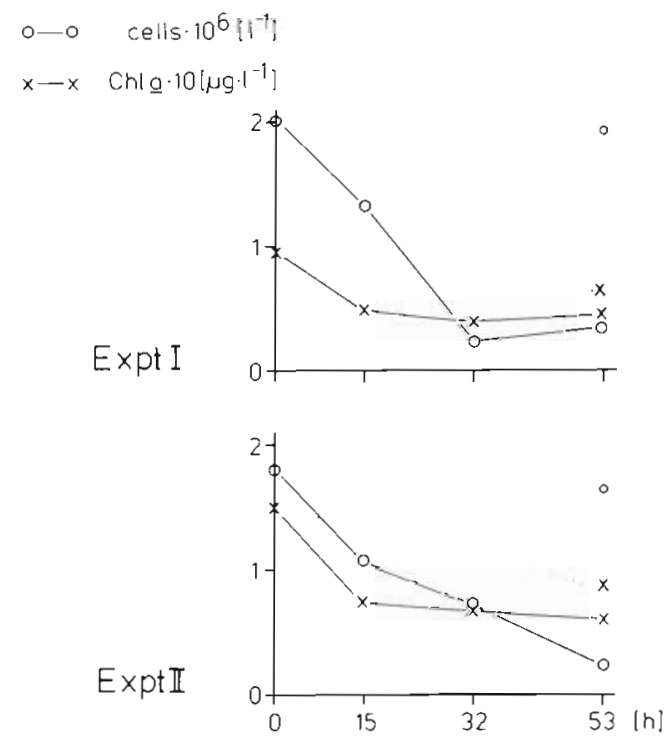

Fig. 6. Decrease in numbers of phytoplankton cells $(-)$ and chl a $(\mathrm{x}-\mathrm{x})$ during copepod grazing Expts I and II. Dotted lines represent controls

(Fig. 6). Pellet production rate decreased with time 10.33 pellets copepod ${ }^{-1} \mathrm{~h}^{-1}$ for the first $15 \mathrm{~h}_{\mathrm{i}} 0.19$ pellets copepod ${ }^{-1} \mathrm{~h}^{-1}$ for $53 \mathrm{~h}$ ).

Contents of faecal pellets produced during Expts I to III by the copepods Calanus finmarchicus and Metridia spp. did not reflect composition of the food organisms. Pellets collected in the first $15 \mathrm{~h}$ of the experiments often contained intact cells of the diatom Thalassiosira nordenskiöldii (Fig. 4a). In contrast, intact cells of Skeletonema costatum were rarely found in faecal pellets (Fig. 4b). Remains of other diatoms species were prominent (Fig. 4b). Pellets collected during the last $20 \mathrm{~h}$ of incubation were comprised of broken diatom frustules and spines (Fig. 4c); intact cells were rare (Fig. 4d). In none of the ca 200 pellets observed could remains of coccoliths be identified although coccolithophorids of diameter 10 to $13 \mu \mathrm{m}$ were components of the food offered.

The average chl a content in the guts of copepods in Expts IV to VI (Fig. 7 ) increased from 2.39 to $8.13 \mathrm{ng} \mathrm{chl}$ a $\operatorname{copepod}^{-1}(\mathrm{n}=7, \mathrm{SD}= \pm 1.1)$ after $2 \mathrm{~h}$ of incubation,

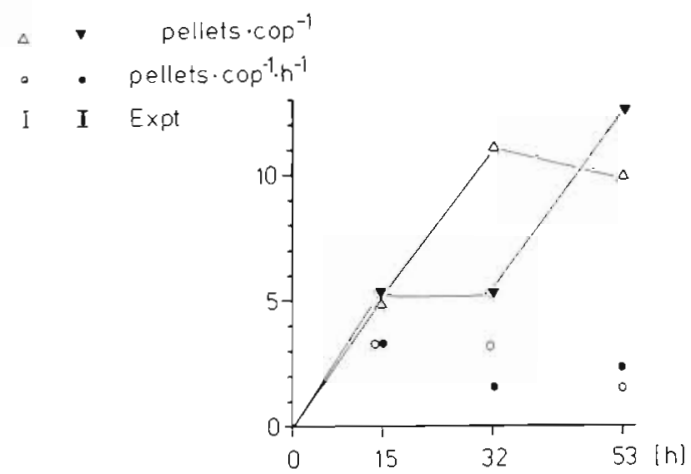

Fig. 7. Copepod faecal pellet production during grazing Expts I (open symbols) and II (closed symbols)

indicating heavy grazing and the ability to adapt quickly to increased food concentrations. After $18 \mathrm{~h}$ gut chlorophyll concentrations had decreased to an average of $2.99 \mathrm{ng}$ chl a copepod $^{-1}$ ( $\mathrm{n}=6, \mathrm{SD}= \pm 0.2$ ).

In Expts VII to XII, in which grazing of copepods from deep water layers $(750$ to $1000 \mathrm{~m}$ ) was investigated, Calanus finmarchicus and Metridia spp. exhibited no feeding activity during $2 \mathrm{~d}$ of incubation; their pigment concentrations were below detectable limits by HPLC and chlorophyll decrease in the incubation bottles did not significantly differ from that of controls. These copepods died within $10 \mathrm{~d}$.

Parallel to these experiments, specimens of the raptorial copepod Euchaeta norvegica from deep water layers were incubated in bottles together with 10 to 20 inactive Calanus finmarchicus. Visual observations during the $3 \mathrm{~d}$ of incubation revealed that $E$. norvegica swam actively in the bottles and caught the immobile C. finmarchicus. E. norvegica almost always held prey fixed with its maxillipeds

\section{DISCUSSION}

In February 1987, 2 sizable stocks of the copepod Calanus finmarchicus were observed in the water column ( 0 to $1400 \mathrm{~m}$ ) on the Voering Plateau in the Norwegian Sea: one near surface $(0-250 \mathrm{~m} ; 1.5$ ind. $\mathrm{m}^{-3}$ ) and a larger stock (130 ind. $\mathrm{m}^{-3}$ ) in deep waters between 500 and $1000 \mathrm{~m}$ (Noji 1989). In the feeding experiments, herbivorous copepods from deep layers did not feed, which is an indication of their dormant 
state, as is typical during their overwintering period (Hirche 1983). The main carnivores (Euchaeta norvegica) from these layers, however, fed on overwintering $C$. finmarchicus. This implies that the stock of overwintering copepods is reduced by carnivory during that time. The effect of carnivory on the reduction of $C$. finmarchicus stocks in a Norwegian fjord can be tremendous (Matthews \& Heimdal 1980). The surviving population of overwinterers will, at least partially, determine the magnitude of the surface population of herbivores of the following year (Colebrook 1985).

The most interesting aspect of our results is the presence of a second stock of copepods which lives at the sea surface during winter and feeds. This was indicated by the pigments found in their guts (a fact also observed by Head \& Harris 1985) and the presence of copepod faecal pellets suspended in the water. This agrees with the findings of Hirche (1983), who reported that copepods in winter in a Norwegian fjord had high digestive enzyme activities, high respiration rates and produced faecal pellets and eggs. The actual ingestion rates of copepods in our study were low probably due to low ambient phytoplankton concentrations (e.g. Dagg \& Walser 1987). Assimilation of ingested material at low food concentrations, however, may be greater than at high food concentrations, as indicated by gut clearance and pigment destruction experiments by Kiørboe \& Tiselius (1987). Of major importance is our observation that, when offered food at concentrations comparable to those typical of spring blooms, surface copepods responded with rapid increases in ingestion rates and gut chl a content (Fig. 7). In contrast, copepods from deep layers did not respond at all to any of the food offered.

Although we do not wish to address the absolute rates measured during these experiments, the rapidity and intensity of the copepod response at the surface to increased food levels are of interest. Potential herbivore feeding activity is, hence, high and any increases in phytoplankton growth in surface waters should be accompanied by intensified grazing activity.

The grazing potential of wintering herbivorous copepods in surface waters probably has consequences for the phytoplankton diatom biomass and species composition during spring. If ingestion rates derived from our experiments are applied, copepod feeding

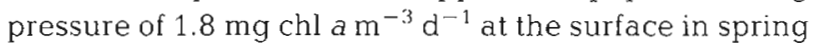
would oppose a primary production rate of about $2 \mathrm{mg}$ chl a m $\mathrm{m}^{-3} \mathrm{~d}^{-1}$ (Peinert et al. 1987), which is typical for spring phytoplankton production in this area (Rey 1981). We suggest that the presence of overwintering herbivorous copepods at the surface during the time of increased phytoplankton diatom production, and the ability of these copepods to respond quickly to higher levels of this food supply, may be one factor for the observed lack of enhanced diatom growth in the Norwegian Sea. Therefore, the consequences of copepod grazing in February 1987 in the Norwegian Sea were comparable to the situation in the high latitude, open-ocean areas of the Pacific, where herbivorous copepods regularly feed throughout the winter period and on spring phytoplankton stocks (Frost et al. 1983, Miller et al. 1984, Vidal \& Smith 1986). In the Pacific, however, microzooplankton grazing more than mesozooplankton feeding may control total phytoplankton biomass (Frost 1987), for which, to our knowledge, no data are available for the Norwegian Sea.

In the Norwegian Sea irregular patterns of zooplankton and phytoplankton abundance in surface waters occur; the time of the copepod maximum may vary by up to 3 mo from year to year (Lie 1968), whereas the corresponding variance for maximal spring phytoplankton growth is barely 1 mo (Rey 1981). In extreme situations this could conceivably lead to the development of a plankton community similar in species composition and mode of primary production to a summer system. In such systems autotrophs are dominated by microflagellates and material is recirculated within the upper mixed layer as described by Smetacek et al. (1984) from a shelf area. Such a situation was encountered in the Norwegian Sea in spring 1986 (Peinert et al. 1987).

Still other factors are at least equally as important for determining composition and magnitude of spring phytoplankton biomass. Vertical mixing will slow phytoplankton accumulation in the euphotic zone. Further, if the upward migration of the bulk of overwintering copepods from deep water strata occurs shortly before or concomitant with increased diatom spring growth, bloom formation could be hindered.

In summary, the timing and duration of the biomass increase in both zooplankton and phytoplankton stocks as well as the grazing potential of herbivores already present in surface waters in late winter/early spring are vital factors affecting the pelagic biological regime of the Norwegian Sea in spring. The success of overwintering diapausal copepods, the timing of their mass migration to the surface and the size of wintering stocks of surface herbivores may be responsible for the occurence of flagellates rather than diatoms in the phytoplankton species composition. A diatom bloom only can be expected when stratification remains strong for a long period, when the late winter standing stock of herbivorous copepods in the near surface waters is fairly small and the occurrence of the upward migration of overwinterers from deep water layers is late relative to increased spring diatom growth. Otherwise, diatom stocks in this area might be controlled by herbivores. 
Acknowledgement. We acknowledge the efforts of the captain and crew of the RV 'Poseidon' in steaming in the Norwegian Sea during winter Helpful comments on the manuscript were given by J. Lenz, M. Voss, U. Passow and 3 unknown reviewers. This is publication No. 62 of the Sonderforschungsbereich 313, University of Kiel.

\section{LITERATURE CITED}

Båmstedt, U. (1975). Studies on deep-water pelagic communities of Korsfjorden, Western Norway. Ecological aspects of individual variations in weight and protein and lipid content of Euchaeta norvegica (Copepoda). Sarsia 59: $31-46$

Bathmann, U. (1988). Mass occurrence of Salpa fusiformis in the spring of 1984 off Ireland: implications for sedimentation processes. Mar. Biol. 97: 127-135

Bathmann, U., Liebezeit, G. (1986). Chlorophyll in copepod faecal pellets: changes in pellet numbers and pigment content during a declining Baltic spring bloom. P.S.Z.N.I. Mar. Ecol. 7: 59-73

Billett, D. S. M., Lampitt, R. S., Rice, A. L., Mantoura, R. F. C. (1983). Stasonal sedimentation of phytoplankton to the deep-sea benthos. Nature, Lond. 302: 520-522

Colebrook, J. M. (1985). Continuous plankton records: overwintering and annual fluctuations in the abundance of zooplankton. Mar. Biol. 84: 261-265

Conover, R. J., Corner, E. D. S. (1968). Respiration and nitrogen excretion by some marine zooplankton in relation to their life cycle. J. mar. biol. Ass. U. K. 48: 49-75

Dagg, M. J., Vidal, J., Whiteledge. 'I' E., Iverson, R. L., Goering, J. J. (1982). The feeding, respiration, and excretion of zooplankton of the Bering Sea during a spring bloom. Deep Sea Res. 29: 45-63

Dagg, M. J., Walser, W. E. Jr (1987). Ingestion, gut passage, and egestion by the copepod Neocalanus plumchrus in the laboratory and in the subarctic Pacific Ocean. Limnol. Oceanogr 32: 178-188

Edler, L. (1979). Recommendations on methods for marine biological studies in the Baltic Sea. Phytoplankton and chlorophyll. BMB Publ. 5: 1-38

Frost, B. W (1987). Grazing control of phytoplankton stock in. the subarctic Pacific Ocean: a model assessing the role of mesoplankton particularly the large calanoid copepods Neocalanus spp. Mar. Ecol. Prog. Ser 39: 49-68

Frost, B. W. Landry, M. R., Hasset, P. R. (1983). Feeding behaviour of large calanoid copepods Neocalanus cristatus and $N$. plumchrus from the subarctic Pacific Ocean. Deep Sea Res. 30: 1-13

Halldal, P. (1953). Phytoplankton investigations trom weathership $M$ in the Norwegian Sea, 1948-49. Hvalrád. Skr 38: $1-91$

Head, E. J. H., Harris, L. R. (1985). Physiological and biochemical changes in Calanus hyperboreus from Jones Sound NWT during the transition from summer feeding to overwintering condition. Polar Biol. 4: 99-106

Hillebrandt, M. (1972). Untersuchungen über qualitative und quantitative Zusammensetzung des Zooplanktons in der Kieler Bucht während der Jahre 1966-1968. Dissertation, Univ. Kiel

Hirche, H. J. (1983). Overwintering of Calanus finmarchicus and Calanus helgolandicus. Mar. Ecol. Prog. Ser. 11 $281-290$

Hopkins, C. C. E., Falk-Petersen, S., Tande, K. S., Eilertsen, H. C (1978). A preliminary study of zooplankton sound scat- tering layers in Balsfjorden: structure, energetics and migrations. Sarsia 63: 255-264

Hopkins, C. C. E., Tande, K. S., Gronvik, S., Sargent, J. R. (1984). Ecological investigations on the zooplankton community of Balsfjorden, northern Norway: an analysis of growth and overwintering tactics in relation to niche and environment in Metridia longa (Lubbock), Calanus finmarchicus (Gunnerus), Thysanoessa inermis (Kroyer) and $T$. raschi (M. Sars). J. exp. mar. Biol. Ecol. 82: 77-99

Jeffrey, S. W., Humphrey, G. F. (1975). New spectrophotometric equations for determining chlorophylls $a, b, c 1, c 2$ in higher plants, algae and natural phytoplankton. Biochem. Physiol. Pflanz. 167: 191-197

Kiørboe, T., Tiselius, P. (1987). Gut clearance and pigment destruction in a herbivorous copepod, Acartia tonsa, and the determination of in situ grazing rates. J. Plankton Res. 9: $525-534$

Lie, U. (1968). Variation in the growth of zooplankton and proportion of Calanus finmarchicus at station $M$ in the Norwegian Sea 1959-66. FiskDir. Skr (Ser Havunders.) 14: $121-128$

Mantoura, R. F. C., Llewellyn, C. A. (1983). The rapid determination of algal chlorophyll and carotenoid pigments and their breadkown products in natural waters by reversephase HPLC. Analytica chim. Acta 151: 297-314

Marshall, S. M., Orr, A. P. (1972). The biology of a marine copepod. Oliver \& Boyd, London

Matthews, J. B. L., Heimdal, B. R. (1980). Pelagic productivity and food chains in fjord systems. In: Freeland, H. J., Farmer, D. M., Levings, C. D. (eds.) Fjord oceanography. NATO Conference Ser. 4: 377-398

Miller, C. B., Frost, B. W., Batchelder, H. P., Clemons, M. J., Conway, R. E. (1984). Life histories of large, grazing copepods in a subarctic ocean gyre: Neocalanus plumchrus. Neocalanus cristatus and Eucalanus bungii in the Northeast Pacific. Prog. Oceanogr. 13: 201-243

Mullin, M. M. (1963). Some factors affecting the feeding of marine copepods of the genus Calanus. Limnol. Oceanogr. 8: $239-250$

Noji, T T. (1989). The influence of zooplankton on sedimentation in the Norwegian Sea. Dissertation, Univ. Kiel

Ostvedt, O.-J. (1955). Zooplankton investigations from weathership $M$ in the Norwegian Sea, 1948-49. Hvalråd. Skr. 40: $1-93$

Omori, M. Ikeda, T (1984). Methods in marine zooplankton ecology. Wileys and Sons Inc., New York

Paasche, D. (1980). Nutrient dynamics: Silicon. In: Morris, I (ed.) The physiological exology of phytoplankton. Studies in ecology 7 Blackwell Sci. Publ. Oxford, p. 259-284

Paffenhöfer, G.-A. (1971). Grazing and ingestion rates of nauplii, copepodids and adults of the marine planktonic copepod Calanus helgolandicus. Mar Biol. 11. 286-298

Peinert, R., Bathmann, U., Bodungen, B. V., Noji, T T (1987). The impact of grazing on spring bloom growth and sedimentation in the Norwegian Current. Mitt. Geolog.Paleontol. Inst. Univ. Hamburg, SCOPE/UNEP Sonderb. 62: $149-164$

Rey, F. (1981). The development of the spring phytoplankton outburst at selected sites off the Norwegian coast. In: Saetre, R., Mork, M. (eds.) The Norwegian Coastal Current. Proc. Norweglan Coastal Current Symp. GEILO, 9-12 Sept. 1980, University of Bergen, Bergen, p. 649-680

Robertson, A. (1968). The continuous plankton recorder: a method for studying the biomass of calanoid copepods. Bull. mar Ecol. 6: 185-223

Smetacek, V (1975). Die Sukzession des Phytoplanktons in der westlichen Kieler Bucht. Dissertation, Univ. Kiel 
Smetacek, V., Bodungen, B. V., Knoppers, B., Peinert, R., Pollehne, F., Stegmann, P., Zeitzschel, B. (1984). Seasonal stages characterizing the annual cycle of an inshore pelagic system. Rapp. P.-v. Cons. int. Explor. Mer 183: $126-135$

Strathmann, R. R. (1967). Estimating the organic carbon content of phytoplankton from cell volume or plasma volume. Limnol. Oceanogr. 12: 411-418

Utermöhl, H. (1931). Über das umgekehrte Mikroskop. Verh. int. Verein theor angew. Limnol. 5: 567-596

This article was submitted to the editor
Utermöhl, H. (1958). Zur Vervollkommnung der quantitativen Phytoplankton-Methodik. Mitt. int. Verein. theor angew. Limnol. 9: 1-38

Vidal, J., Smith, S. L. (1986). Biomass, growth, and development of populations of herbivorous zooplankton in the southeastern Bering Sea during spring. Deep Sea Res. 33: 523-556

Wiborg, K. R. (1954). Investigations on zooplankton in coastal and offshore waters of western and northwestern Norway. FiskDir. Skr. (Ser Havunders.) 11: 1-245

Manuscript first received: October 18, 1988

Revised version accepted: November 24, 1989

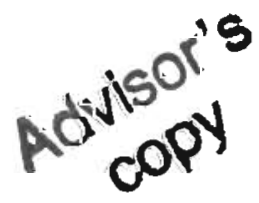

